\title{
Knowledge of medical school students on breast cancer and cervical cancer, and their prevention
}

\author{
Wiedza studentów uczelni medycznych na temat profilaktyki raka piersi i szyjki \\ macicy
}

\author{
Anna Liszcz'1 Anna M. Badowska-Kozakiewicz² \\ 'Students' Scientific Organisation, Medical University of Warsaw, Warsaw, Poland \\ Head of the Organisation: Prof. Wiesław Jędrzejczak MD, PhD \\ ${ }^{2}$ Department of Human Biophysics and Physiology, Medical University of Warsaw, Warsaw, Poland \\ Head of the Department: Prof. Jacek Przybylski MD, PhD
}

Key words: breast cancer, cervical cancer, prevention.

Słowa kluczowe: rak piersi, rak szyjki macicy, profilaktyka.

\begin{abstract}
Introduction: Breast cancer and cervical cancer are the most common cancers in women. Early diagnosis of the disease can reduce mortality, so it plays an important role in the field of prevention measures. An important aspect is education, the aim of which is to provide information on the risk factors for cervical cancer and breast cancer, as well as the possibility of eliminating them from the life of women, but also shaping women's need to perform regular diagnostics.

Aim of the research: To evaluate the level of knowledge and its practical application in the private lives of medical school students. Material and methods: Two hundred and fifty female medical school students from different faculties were invited to take part in the investigation. The research used an original questionnaire by the authors.

Results: The statistical analysis showed highly developed theoretical knowledge in the field of cancer prevention. The following risk factors of breast cancer were mentioned: genetic factors (87.6\%) and age (65.2\%); and risk factors of cervical cancer: numerous sexual partners (77.2\%) and past viral infections (72\%). Nevertheless, despite their knowledge on HPV influence on cervical cancer development, BRCA gene mutations, and other associated risk factors, $63.6 \%$ of students considered their knowledge unsatisfactory. Moreover, breast self-examinations were performed by $86 \%$ of respondents but only $44.5 \%$ had Pap tests performed.

Conclusions: Despite the medical education of the respondents, it is highly recommended that actions aimed at promoting preventive diagnostics be intensified. Even though the students showed a high level of theoretical knowledge, it is crucial to increase and promote its practical application.
\end{abstract}

\section{Streszczenie}

Wprowadzenie: Rak piersi i rak szyjki macicy to najczęściej występujące nowotwory złośliwe u kobiet. Wczesne rozpoznanie choroby pozwala zmniejszyć umieralność, dlatego tak ważną rolę odgrywają działania z zakresu profilaktyki. Ważnym aspektem jest edukacja, której celem jest dostarczanie informacji na temat czynników ryzyka rozwoju raka szyjki macicy i raka piersi oraz możliwości wyeliminowania ich z życia kobiet, jak również kształtowanie u kobiet potrzeby wykonywania regularnej diagnostyki.

Cel pracy: Ocena wiedzy studentów uczelni medycznych na temat profilaktyki raka piersi i szyjki macicy.

Materiał i metody: Dwieście pięćdziesiąt studentek uczelni medycznych z różnych kierunków wzięło udział w badaniu, które polegało na wypełnieniu autorskiej ankiety, zawierającej zarówno pytania zamknięte wielokrotnego i jednokrotnego wyboru, jak i pytania otwarte.

Wyniki: Analiza statystyczna wyników badań wskazuje na wysoki poziom wiedzy teoretycznej dotyczącej profilaktyki raka wśród osób badanych. Studentki biorące udział w ankiecie najczęściej jako czynniki ryzyka raka piersi wskazywały czynniki genetyczne $(87,6 \%)$ i wiek $(65,2 \%)$, natomiast wśród czynników ryzyka rozwoju raka szyjki macicy wielu partnerów seksualnych $(77,2 \%)$ oraz przebyte infekcje wirusowe $(72 \%)$. Chociaż wiedza teoretyczna respondentek na temat znaczenia infekcji HPV, mutacji genów BRCA oraz innych czynników ryzyka jest znaczna, $63 \%$ z nich uważa swoją wiedzę za niesatysfakcjonującą. Ponadto samobadanie piersi wykonuje $86 \%$ respondentek, a badanie cytologiczne tylko $44,5 \%$.

Wnioski: Pomimo edukacji medycznej ankietowanych wyniki badań wskazują, że należy poszerzać wiedzę w zakresie profilaktyki nowotworów. Badane studentki prezentują wysoki poziom wiedzy teoretycznej, ale należy zwiększać i promować jej praktyczne zastosowanie. 


\section{Introduction}

Cancer is a disease that affects Polish society more and more commonly. According to predictions on cancer incidence rates in Poland, there will be a systematic growth in the number of new cases, both among men and women [1]. This condition is a consequence of higher exposure to carcinogens related to civilisation progress, and also to inappropriate lifestyle [1]. The incidence of cancer in Poland is estimated to at approximately 140.5 thousand cases per year, with more than half of the cases (70.5 thousand) concerning women. Breast cancer takes the second place among the most frequent cancers in women, with $13 \%$ of known cases. However, cervical cancer with a rate of $4 \%$ of known cases takes the seventh place. Doctors and other medical staff are constantly undertaking a variety of activities aimed at increasing awareness of risk factors of breast cancer and cervical cancer. Thanks to them, the awareness and knowledge among women are constantly being broadened. However, it is not recommended to stop further efforts at raising cancer awareness, both in older and younger women. It is crucial to pay attention to the education of younger members of our society, knowing that cancer incidence in women aged from 20 to 44 years is rising $[1,2]$. There are a number of risk factors predisposing to breast cancer development, with one of the most discussed being the influence of BRCA1/ BRCA2 gene mutation, which raises the risk of illness from $50 \%$ do $80 \%$ [2]. Other factors are: age, usage of hormone replacement therapy (such as oestrogen replacement therapy or hormonal contraception), and previously diagnosed benign breast conditions (lipo-

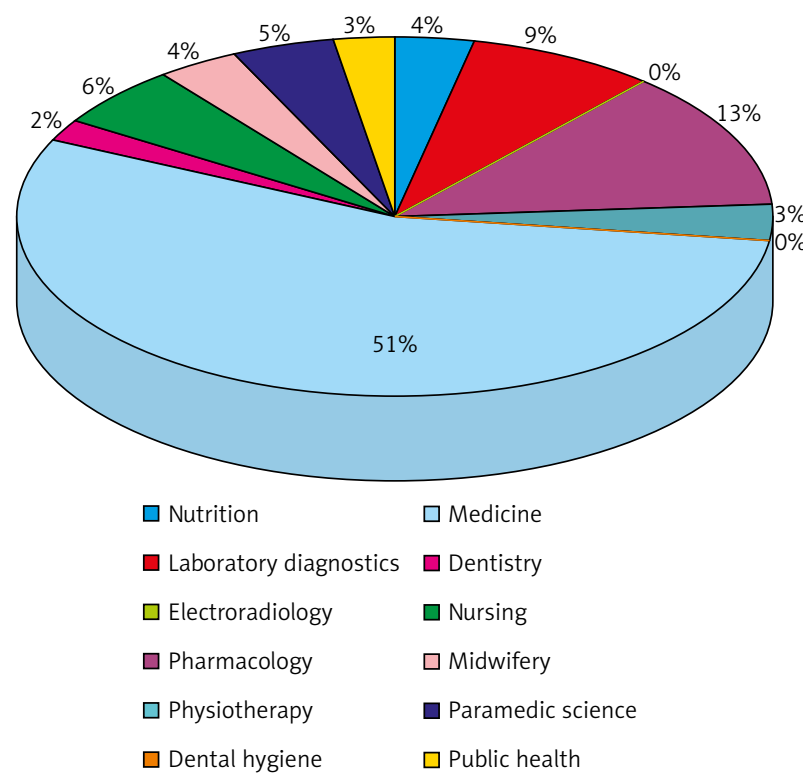

Figure 1 . The percentage summary of study programs of students taking part in the research ma, fibroma) [2]. As far as cervical cancer is concerned, the influence of human papilloma virus (HPV) is the most widely discussed. Nowadays it is thought that HPV is responsible for about $70 \%$ of cases of cervical cancer. Therefore, any infections leading to epithelial neoplasia increase the risk of developing this type of cancer. In every type of cancer, one of the most essential factors describing the chances for long-term survival is the moment of proper diagnosis. The tumour stage and time of therapy implementation affect the therapeutic effects of the applied treatment. There is a significant correlation between rapid cancer detection and high long-term survival rate. Proper prevention and knowledge of the most frequent symptoms suggesting cancer are the key to its early detection. This leads to higher chances for long-term recovery. Therefore, it is highly recommended that women be informed about methods of early diagnosis of tumours of the breasts and cervix, the need for preventive diagnostics, and for education on the most frequent symptoms and risk factors. The number of women in medical society is systematically rising, which should be connected with increasing knowledge among female medical staff about the risks of cancer. Despite their specialities as doctors, nurses, pharmacists, or paramedics, each of them should have contact with cancer patients. The chances are also high that they will have contact with oncology in their private life [4-7].

\section{Aim of the research}

The aim of this study was to assess the knowledge of female medical school students of different specialities regarding breast cancer and cervical cancer, and to verify if their future medical professions influence their attitude towards preventative health behaviour. Moreover, a more detailed insight into the given answers may help to identify if there is a difference between the levels of knowledge of students of different faculties.

\section{Material and methods}

This study concluded 250 females aged from 19 to 28 years $(\mathrm{SD}=3.16)$, students of Polish Medical Universities: in Bialystok, Gdansk, Lodz, and Warsaw. The students' state of knowledge was evaluated on the basis of an original questionnaire written by the authors, which was created for the purpose of this study. The questionnaire was completed anonymously by students willing to do so. The survey consisted of 26 questions (22 questions were closed and 4 were open), with one of them being non obligatory. The questions were divided into two sections. The first one concerned scientific data on breast cancer and cervical cancer, and the second one involved questions about personal experience in the discussed field. 
The percentage of given answers was considered the primary source of data.

Our survey included students of medical faculties such as: laboratory diagnostics (23 persons), nutrition (10), electroradiology (1), pharmacology (31), physiotherapy (6), dental hygiene (1), medicine (127), dentistry (6), nursing (15), midwifery (9), paramedic science (11), and public health (8). The students represented different grades of studies, from I to III (baccalaureate study program), IV to V (complementary master's), and from I to V or VI (Figure 1).

\section{Results}

Taking into account the fact that the respondents were medical students, there was a high chance that the survey would show a high level of knowledge on breast and cervical cancers. That was confirmed by the obtained results. As many as $74.0 \%$ of students participating in the study had contact with oncology during their studies. Oncological prevention was discussed at a satisfactory level. However, it should be noted that $85 \%$ of interviewed students will not attend any other classes on this subject matter in the course of their studies. The vast majority of respondents considered social campaigns promoting women's knowledge about cancer as definitely necessary and certainly raising their consciousness about the prevention methods. A high percentage of students $(86.8 \%)$ knew about the influence of BRCA1/BRCA2 gene mutation on the development of breast cancer, $79.6 \%$ of them chose the correct percentage risk linked to the above-mentioned mutation, but $11.2 \%$ of respondents pointed to a higher risk while $9.2 \%$ chose a too low risk. The influence of HPV infection on the development of cervical cancer was noted by $97.2 \%$ of respondents. However, they pointed to different rates of cases induced by HPV: $38.4 \%$ of students marked $30 \%$ of cases as directly linked to viral infection, $37.2 \%$ pointed to $50 \%$ of cases, and $24.4 \%$ of respondents marked $70 \%$.

Considering that actually $70 \%$ of cervical cancer cases are caused by HPV-16 or HPV-18 infection [3], additional efforts should be undertaken to provide information on the severity of those infections and their correlation with cancer. The most frequently given disturbing symptom that would persuade women to start diagnostics was a lump in the breast (it was indicated by 249 of 250 respondents). The next most disturbing signs were intermenstrual bleeding and nipple discharge (ex aequo 229 respondents). Out of 12 risk factors, 6 should actually push the patient to perform diagnostic tests in order to eliminate the above-mentioned neoplasms. Only 14 people gave the correct combination of risk factors (Figure 2).

It should be noted that the respondents indicated certain signs as disturbing, while they are not related to an elevated risk of breast cancer or cervical cancer,

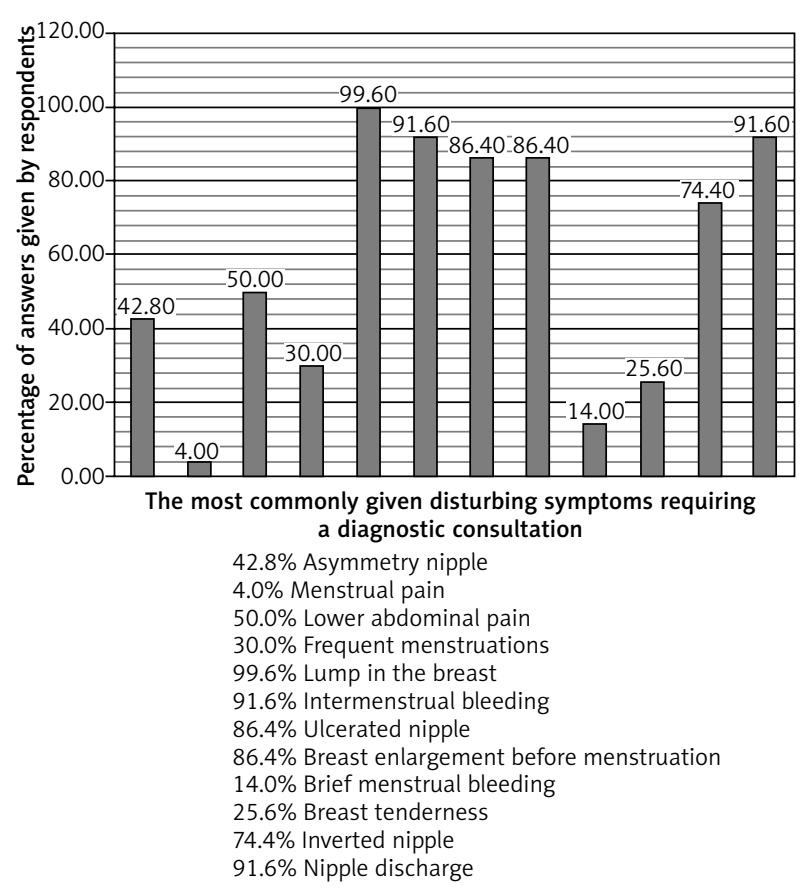

Figure 2. The most frequently given disturbing symptoms requiring a diagnostic consultation of suspected breast cancer or cervical cancer

such as frequent menstrual bleeding (75 answers), breast tenderness (64 answers), or brief menstrual bleeding (35). The most frequently given risk factors of cervical cancer were a high number of sexual partners $(193 / 250)$ and past viral infections (180/250). Other frequent causes noted by respondents were: smoking cigarettes (141/250), hormonal therapies (132/250), immunosuppression (118/250), and polycystic ovary syndrome (PCOS) (88/250). Only one student gave the correct combination of risk factors (Figure 3).

The high number of respondents who indicated PCOS as a significant risk factor of cervical cancer should be noted, because the influence of the disease on cervical cancer development has not been confirmed. However, there is a connection between PCOS and ovarian cancer development, so a high number of the answers followed from generalisation regarding neoplasms of the genitals, which are very common among women, and also among women working in medical facilities. In cases of breast cancer, the most significant role was associated with genetic factors concerning mutations of genes BRCA1 and BRCA2 $(219 / 250)$, and hereditary factors (223/250). Furthermore, age was frequently noted $(163 / 250)$, as well as hormonal contraception (145/250), using hormone replacing therapy (141/250), and cigarette smoking $(134 / 250)$. Only three respondents chose the correct combination of all given risk factors (Figure 4).

Cancer prevention is a very important issue. Most of the respondents considered the frequency of one Pap test per year as correct $(67.6 \%-169$ individuals). 


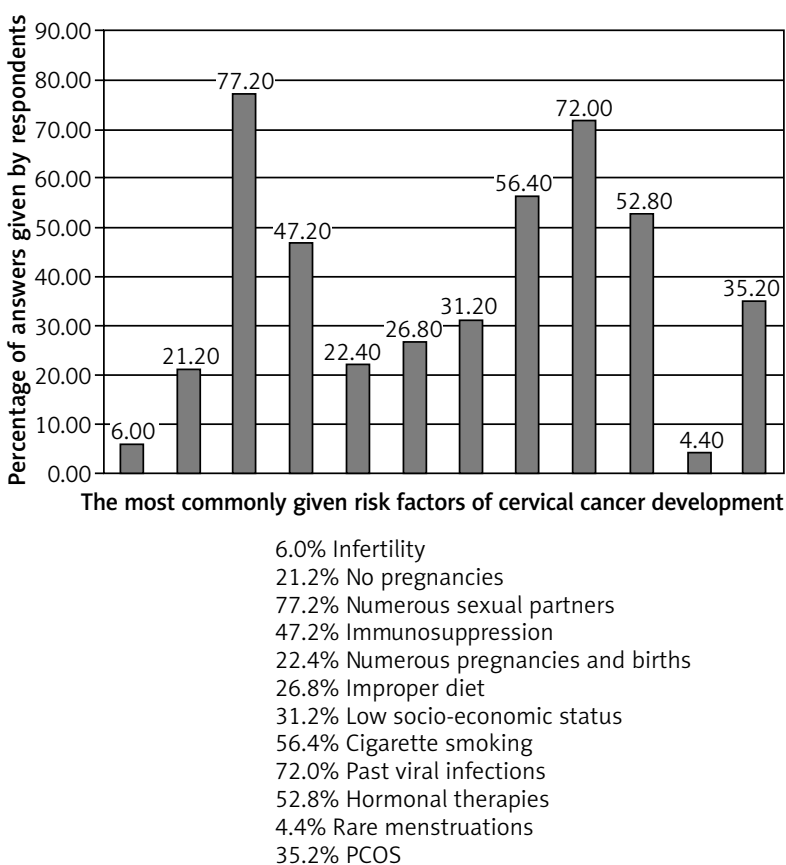

Figure 3. The most commonly given risk factors of cervical cancer

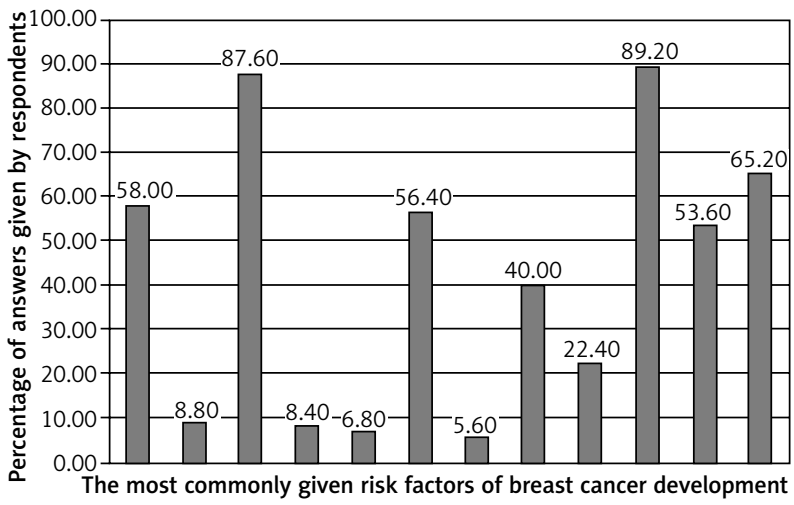

$$
\begin{aligned}
& \text { 58.0\% Hormonal contraception } \\
& \text { 8.8\% Infertility } \\
& \text { 87.6\% Genetic factor } \\
& \text { 8.4\% Numerous sexual partners } \\
& \text { 6.8\% Large size of breast } \\
& 56.4 \% \text { HRT } \\
& 5.6 \% \text { Numerous pregnancies and births } \\
& \text { 40.0\% Bengn breast tumors } \\
& 22.4 \% \text { Improper diet } \\
& \text { 89.2\% Hereditary factor } \\
& \text { 53.6\% Cigarette smoking } \\
& \text { 65.2\% Age }
\end{aligned}
$$

Figure 4. The most commonly given risk factors of breast cancer

However, 31\% considered a 3-year interval between Pap tests as adequate, and $0.8 \%$ (two respondents) marked "once a month". It should be noted that 55.2\% admitted to never having undergone this examination. This suggests that in most cases the knowledge on time intervals between Pap tests is correct, yet applying this knowledge in everyday life is not so satisfactory. Regarding the frequency of breast self-examinations and the phase of the menstrual cycle during which they should be performed, $85.2 \%$ of students believed that the exams should be performed every month, on the $6-9^{\text {th }}$ day of the cycle. A total of $9.2 \%$ of respondents considered as correct the answer suggesting examination once every month, on the day of predicted ovulation. Two students $(0.8 \%)$ suggested the examination should be carried out every 6 months, on the day of predicted ovulation, and another two students considered "once a year" as a correct time interval, on the day of predicted ovulation. One student marked the answer "once a year" on the $6-9^{\text {th }}$ day of the cycle. A total of $86 \%$ of respondents performed breast self-examination. However, $14 \%$ had never done it before. It is crucial to realise that $17.6 \%$ did not consider the time of examination in the cycle as relevant for the result. The great majority of students gave the correct, recommended frequency of self-examination, but a significant number of respondents suggested a different clinical solution. Moreover, the majority of the respondents considered breast self-examination and Pap test as essential in early cancer diagnostics (96.8\%). An even higher number of respondents $(98.0 \%)$ considered that the above-mentioned examination and ultrasonography of breasts or mammography (depending on the patient's age) should be performed by each woman. Both in the case of a selfpalpated lump in one breast $(95.6 \%)$ or observation of cervical mucus abnormalities (95.4\%), the vast majority of respondents considered that an immediate visit to the doctor's surgery was necessary. Postponement of the examination was suggested by $3.6 \%$ of students, in order to observe any changes, i.e. whether the symptom persisted or not; $0.8 \%$ suggested no reaction due to proximity to breast lobules, imitating a lump. A total of $1.2 \%$ of respondents relied on a single abdominal pain or mucus change. Therefore, it may be concluded that the necessity of a rapid diagnosis is dominant. Nevertheless, $26.0 \%$ of students would not take any actions concerning cancer prevention; $18.4 \%$ of them would still consider such actions as necessary, while $7.6 \%$ did not consider any of them necessary. In the course of the analysis of data derived from the surveys after applying filters that selected every correct answer concerning theoretical knowledge on HPV and BRCA gene mutations, as well as necessary preventive diagnostics, 79 persons were identified as showing adequate knowledge. Among them, 6 had never performed a breast self-exam, and as many as 39 of them never had a Pap test. This proves a high level of awareness concerning the causes and symptoms of breast cancer and cervical cancer, and the necessity of preventive diagnosis. However, this does not correlate with practical application of that knowl- 
edge. Eleven from among 250 respondents confirmed a family history of breast cancer or cervical cancer; all of them performed breast self-exams, but two of them had never had a Pap test. One student did not apply rules of cancer prevention, even though she believed she should; also one of the respondents was carrying out preventive diagnostic tests even though she considered them unnecessary.

\section{Discussion}

Taking into account the fact that the respondents, being students of medical universities, took part in numerous classes on health prevention, their knowledge on that matter should be much better than among women of approximately the same age but studying at different faculties. According to the data from the National Cancer Registry, students of medical universities show a much higher level of knowledge than their peers from universities of different profiles. In the study performed by Kalinowski and Wala (2014), $57 \%$ of students of the Medical University of Lublin gave correct answers concerning HPV-related cervical cancer. In this study, the correct answer was given by $97.2 \%$ of respondents [8]. Cichońska et al. in their study checked the knowledge of 50 randomly chosen women of all ages, from Ostroleka voivodeship [9]. They obtained different data than us. In questions concerning risk factors of breast cancer, hormonal contraception was listed by $17 \%$ of women, smoking cigarettes by $31 \%$, and age by only $19 \%$ [9]. In questions concerning risk factors of cervical cancer, numerous sexual partners were chosen by $58 \%$, smoking cigarettes by $20 \%$, and past viral infections by $66 \%$. In our study, in analogous questions on breast cancer, the same answers were chosen by $58 \%, 53 \%$, and $65 \%$, respectively [10]. In questions referring to cervical cancer, the same risk factors were pointed out by $77.2 \%, 65.4 \%$, and $72 \%$, respectively. This leads to the conclusion of greater knowledge will be had by future medical staff. In our study, $63.6 \%$ of students considered their knowledge insufficient in the field of breast cancer and cervical cancer prevention. UlmanWłodarz et al. evaluated the awareness among patients of gynaecological outpatient clinics about cervical cancer prevention [11]. Despite them being under constant control of their gynaecologist, $21 \%$ of them had never had cytology. Sixteen percent correctly pointed out lower abdominal pain as a symptom of developed disease, and $49 \%$ pointed out that HPV is responsible for cervical cancer development. In comparison with our study, the same answers were given by $44.8 \%$, $50 \%$, and $72 \%$, respectively. Kalinowski et al. showed differences between knowledge among the students of the Faculty of Nursing and Health Sciences of the Medical University of Lublin and the working women of the region of Lublin [12] about breast cancer and its risk factors. Students showed high accuracy with pointing out contraceptive pills (82.4\%), hormonal replacement therapy (68.9\%), and genetic factors $(94.5 \%)$ as risk factors of breast cancer, which was less precise than in our study $(58.0 \%, 56.5 \%$, and $87.6 \%$, respectively). Gerstenkorn et al. conducted a study to find out if economically active nurses from the Lodz region sufficiently connected tobacco smoking with higher risk of cervical cancer [13]. Out of 107 women, $59 \%$ of respondents correctly indentified this risk factor, which is more than in our study (56\%). Thus, we may conclude that cigarette smoking was slightly more associated with this cancer development.

Although the students of medical universities clearly showed higher awareness of the most important risk factors and symptoms of cancer, they frequently presumed the significance of symptoms not proven by any scientific data. A prominent example is the alleged influence of PCOS on cervical cancer development. More than 35\% of respondents considered this disease as predisposing to the above-mentioned type of cancer, although this is not confirmed by any scientific data. Moreover, it should be underscored how underestimated is the influence of improper diet on both breast cancer and cervical cancer.

Irrespective of the respondents' level of knowledge, it is crucial to intensify activities aimed at raising women's awareness and knowledge about breast cancer and cervical cancer prevention and symptoms (those very and less characteristic), which when properly diagnosed, can influence the effect of treatment.

It is important to emphasise that this kind of research is needed to evaluate cancer awareness. Although it is common to assess women's knowledge, a questionnaire verifying education among young women, especially medical students, is rare or the results remain unpublished. Thus, the continuity of this study should be preserved and performed on larger numbers of students, both for realising gaps in knowledge and verifying if that knowledge is up-todate.

We analysed 250 female medical school students. This represents approximately $0.004 \%$ of medical students in Poland, taking into account the total number of medical students in Poland. This low number results from the voluntary character of the performed questionnaire and the lack of global access of this inquiry. Another questionnaire with larger number of participants should be performed, in order to increase the representativeness of this study.

\section{Conclusions}

The results of the current study indicate that the knowledge of students of medical universities about breast cancer and cervical cancer is satisfactory, and significantly better than among their peers from different universities, although in many students it requires improvement. Highly developed theoretical 
knowledge in the field of cancer prevention does not always correlate with its practical application in private life. Despite students' knowledge on HPV influence on cervical cancer development, the vast majority understated the percentage of cases of this type of cancer resulting from a past infection with the abovementioned virus. Informative actions should be reinforced. As regards proper measures taken in case of the presence of disturbing symptoms, the majority of students considered the implementation of diagnostic procedures necessary as quickly as possible, which confirms a high level of their health consciousness, which is connected with a higher long-term survival rate in cases of early-diagnosed cancer. A study involving larger numbers of participants should be performed in order to increase the representativeness.

\section{Conflict of interest}

The authors declare no conflict of interest.

\section{References}

1. Didkowska I, Wojciechowska U, Zatoński W. Cancer in Poland in 2009. Maria Skłodowska-Curie Memorial Cancer Center, Department of Epidemiology and Cancer Prevention, Polish National Cancer Registry, Warsaw 2009. Available at: http://onkologia.org.pl/wp-content/uploads/Prognozy_2025.pdf (access: 2014.08.22).

2. Kordek R, Jassem J, Jeziorski A, et al. Oncology. Via Medica, Gdańsk 2013

3. Basta A, Bednarek W, Bekiesińska-Figatowska M. Cervical cancer. Prevention, diagnostics, treatment. PZWL, Warsaw 2009.

4. Świątoniowski G. Breast cancer prognosis. PZWL. Health Forum. Available at: http://www.forumzdrowia.pl/ id,303,art,446,ptitle,rokowanie-w-raku-piersi.htm.

5. Didkowska J, Wojciechowska U. Cancer incidence and mortality in Poland. National Cancer Registry, Maria Skłodowska-Curie Institute of Oncology. Available at: http://onkologia.org.pl/nowotwory-zlosliwe-ogolem-2/ (access: 2014.08.22).

6. Kowalczyk M. Breast cancer. National Cancer Registry, Maria Skłodowska-Curie Institute of Oncology. Available at: http://onkologia.org.pl/nowotwory-piersi-kobiet/ (access: 2014.08.22).

7. Rekosz M. Cervical cancer. National Cancer Registry, Maria Skłodowska-Curie Institute of Oncology. Available at: http://onkologia.org.pl/nowotwory-szyjki-macicy-kobiet/ (access: 2014.08.22).

8. Kalinowski P, Wala S. Knowledge on risk factors and prophylaxis of cervical cancer in female students of Lublin. Probl Hig Epidemiol 2014; 9: 460-4.

9. Cichońska M, Borek M, Krawczyk W, et al. Women's knowledge concerning breast tumour and cervical carcinoma prevention. Acta Sci Acad Ostroviensis 2012; 1: 5-25.

10. Chittendenemail BG, Fullerton G, Maheshwari A, et al. Polycystic ovary syndrome and the risk of gynaecological cancer: a systematic review. Reproductive BioMedicine Online 2009; 19: 398-405.
11. Ulman-Włodarz I, Nowosielski K, Romanik M, et al. Awareness of cervical cancer prevention among patients of gynecological outpatient clinic. Ginekol Pol 2011; 82: 22-5.

12. Kalinowski P, Bojakowska U, Kowalska M. Comparative analysis of the level of knowledge of the breast cancer epidemiology in female students and working women. J Educ Health Sport 2015; 5: 353-64.

13. Gerstenkorn A, Kulawiec K, Suwała M. Characteristic features accompanying the development of addiction to drugs. Med Rev 2012; 69: 965-8.

\section{Address for correspondence:}

Anna M. Badowska-Kozakiewicz MD

Department of Human Biophysics and Physiology

Medical University of Warsaw

ul. Chałubińskiego 5, 02-004 Warsaw, Poland

E-mail: abadowska@op.pl 